\title{
EFFECTS OF GLYCEROL AND DIAMETER OF HOLES IN BREAKER PLATE ON PERFORMANCE OF SCREW MIXER FOR NANOCOMPOSITES
}

\author{
A. Fadeyibi ${ }^{\mathrm{a*}}$, Z.D. Osunde ${ }^{\mathrm{b}}$, M.G. Yisa ${ }^{\mathrm{a}}$ \\ a Department of Food, Agricultural and Biological Engineering, Kwara State University, Malate, \\ Nigeria \\ ${ }^{\mathrm{b}}$ Department of Agricultural and Biosystems Engineering, Landmark University, Omuaran \\ *Corresponding author: e-mail: adeshina.fadeyibi@kwasu.edu.ng
}

\begin{tabular}{|c|c|}
\hline ARTICLE INFO & ABSTRACT \\
\hline $\begin{array}{l}\text { Article history: } \\
\text { Received: June } 2017 \\
\text { Received in the revised form: } \\
\text { August } 2017 \\
\text { Accepted: September } 2017 \\
\end{array}$ & $\begin{array}{l}\text { A breaker plate of a screw mixer is an efficient mixing device for use } \\
\text { in homogenizing nanocomposites. This research was undertaken to } \\
\text { investigate the effects of glycerol and diameter of holes in a breaker } \\
\text { plate on performance of a screw mixer for nanocomposites. Samples } \\
\text { of the nanocomposites were formulated by blending } 1000 \mathrm{~g} \text { cassava }\end{array}$ \\
\hline $\begin{array}{l}\text { Key words: } \\
\text { breaker plate, } \\
\text { mixing index, } \\
\text { nanocomposites, } \\
\text { screw mixer }\end{array}$ & $\begin{array}{l}\text { starch, } 45-55 \% \text { glycerol and } 2 \% \text { magnetite nanoparticles; and used to } \\
\text { evaluate the performance of a locally developed screw mixer at } 5 \mathrm{~mm} \\
\text { and } 7 \mathrm{~mm} \text { diameters of holes in its breaker plate. The effects of glyc- } \\
\text { erol and diameter of holes in the breaker plate on mixing index, } \\
\text { amount of unmixed nanocomposites and output/ } 1000 \mathrm{~g} \text { were evaluated } \\
\text { as performance indices for } 1 \text { hour. Empirical models were determined } \\
\text { for predicting the performance of the mixer within the designed } \\
\text { criteria. The results showed that the output/ } 1000 \mathrm{~g} \text { and the mixing } \\
\text { index increased with higher glycerol and diameter of holes in the } \\
\text { breaker plate. However, the amount of unmixed nanocomposites } \\
\text { decreases with a higher diameter of holes in the breaker plate } \\
\text { (p<0.05). The maximum output/ } 1000 \mathrm{~g} \text { and mixing index lies between } \\
5 \text { mm diameter of holes in the breaker plate and } 55 \% \text { glycerol concen- } \\
\text { tration with an approximate desirability of } 0.60 \text {. The empirical models } \\
\text { developed were fit }\left(\mathrm{R}^{2}=0.89 \text {, p }<0.05 \text { ); and there were no significant }\right. \\
\text { differences between actual and predicted values. The results suggest } \\
\text { application of } 5 \text { mm diameter of holes in the breaker plate for homog- } \\
\text { enizing nanocomposites for optimum performance. }\end{array}$ \\
\hline
\end{tabular}

\section{Introduction}

Nanocomposites can be regarded as a homogeneous mixture of different materials, which include one or more nanoparticles and an organic or inorganic constitute. It is difficult to homogenize nanocomposites manually because of the small size of nanoparticles $\left(\simeq 10^{-9} \mathrm{~m}\right.$ ) compared to other constituents in the mixture. In most cases, a homogenizer is required for an effective mixing operation. A good example of a homogenizer is a screw 
mixer equipped with extrusion facilities, such as an auger, breaker plate and die (Fadeyibi et al., 2016a). A degree of mixing, however, depends on the friction heat and the pressure exerted in the machine. The greater the friction heat and pressure buildup against the breaker plate, the more homogeneous are the nanocomposites.

A breaker plate is a circular piece of steel with a number of holes drilled through it and usually located at the exit end of a screw mixer, as shown in Figure 1. The breaker plate provides a seal for containing the high pressure nanocomposites between the mixer diehead and the barrel (Jiang and Zhu, 2008). The restriction offered by this arrangement ensures effective mixing of the nanocomposites. Moreover, routine maintenance of the breaker plate is necessary to avoid materials stuck-up and holes blockage. It is required that the breaker plate be dismantled, cleaned up and coupled whenever the holes are blocked. Alternatively, the old breaker plate can be discarded and replaced with a new one. Thus, one can be sure that the performance of the mixer will be enhanced.

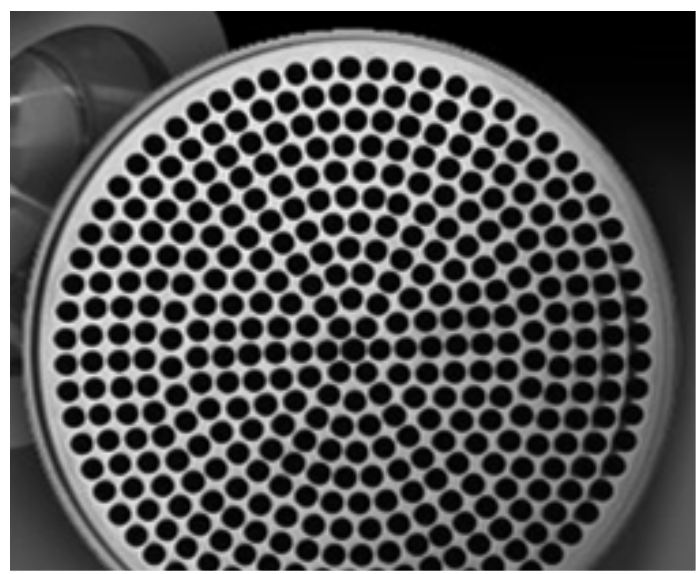

Figure 1. Typical breaker plate holes (Source: JoeTools, 2009)

Modeling of the mixing behavior has been reported for many types of screw mixers (Fadeyibi et al., 2016a; Hu and Chen, 2006; Potente et al., 1994). Hu and Chen (2006) established three dimensional isothermal flow models of kneading-disc elements for a tri screw mixer with the finite element method and emphasized the analysis of materials flow in the machine. Potente et al. (1994) reported a chaotic mixing behavior in the twin screw mixer due to its relatively complex geometry and long development time. The design of the screw mixer for homogenizing bulk solids has been reported by Fadeyibi et al. (2016a), but the performance of the machine was not considered in the design. Moreover, there was no available information on the influence of a diameter of the breaker plate on the performance of the screw mixer. Consequently, there is a need to investigate the performance of nanocomposites at different diameter of holes in the breaker plate. The objective of this research was to investigate the effect of the glycerol level and diameter of holes in the breaker plate on the performance of an existing screw mixer for use in homogenizing nanocomposites. 
Effect of glycerol...

\section{Materials and Methods}

\section{Materials}

Materials used in this investigation, were cassava starch, glycerol and magnetite nanoparticles. The starch was prepared from cassava tubers according to the method described by Fadeyibi et al. (2014). Analytical grade glycerol used was obtained from the Science Education Development Institute (SEDI), Niger State, Nigeria. Magnetite nanoparticles were prepared by adding $0.65 \mathrm{~g}$ of ferric chloride and $0.12 \mathrm{~g}$ of iron powder to $20 \mathrm{~mL}$ hexane solution containing $6.0 \mathrm{~g}$ of dedecylamine and $3.5 \mathrm{~mL}$ of oleic acid at the room temperature. The resulting mixture was transferred into a $60 \mathrm{~mL}$ Teflon lined stainless autoclave. The autoclave was sealed and maintained in an electric oven at $180^{\circ} \mathrm{C}$ for $24 \mathrm{~h}$ and then cooled to the room temperature naturally. The product was washed in absolute ethanol several times followed by centrifugation at $1500 \mathrm{rpm}$ for $5 \mathrm{~min}$ and finally dried in a vacuum at $60^{\circ} \mathrm{C}$ for $8 \mathrm{~h}$ (Anuku 2012). Thus, nanocomposites were prepared by adding $45 \%$ to $55 \%$ glycerol and $2 \%$ magnetite nanoparticles to $1000 \mathrm{~g}$ of the starch.

\section{Methods}

Description of a screw mixer and working principle

A locally developed screw mixer, shown in Figure 2, was used to mix and homogenize $1000 \mathrm{~g}$ of the nanocomposites. The extent of dispersion and distribution of particles in the nanocomposites as well as the performance of the machine were analyzed at $5 \mathrm{~mm}$ and 7 $\mathrm{mm}$ diameters of the holes in the breaker plate.

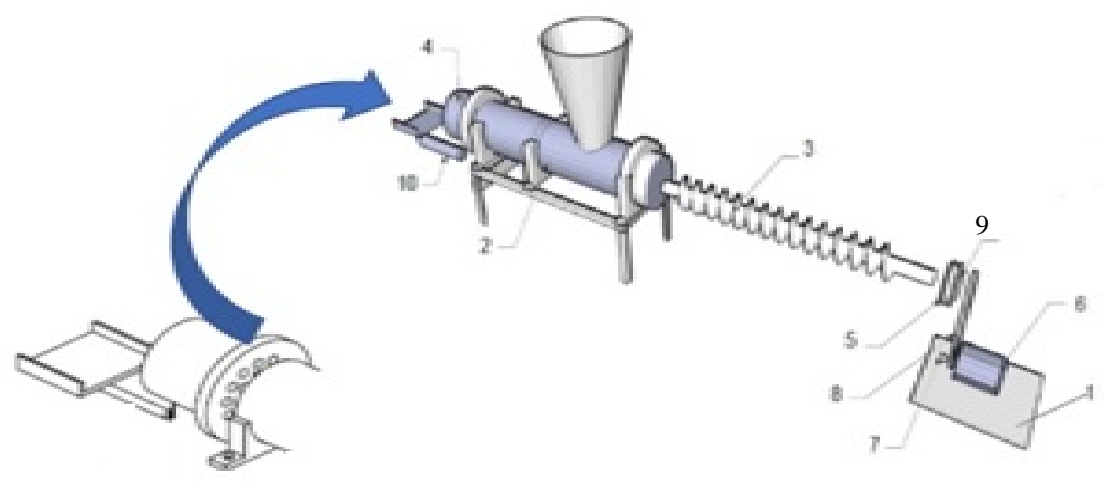

(Source: Fadeyibi et al., 2016a)

Figure 2. Assembly drawing of the screw mixer showing breaker plate attached to die head (1 - Electric motor seat, 2 - Extrusion barrel, 3 - Auger, 4 - Die head, 5 - Pulley, 6 -Electric Motor, 7 - Motor pulley, 8 -Belt drive, 9 - Tip, 10 -Collector) 


\section{Performance Evaluation}

Mixer output

Initial mass of the nanocomposites is essential in determining the output of the developed machine. The value of the bulk density of the nanocomposites reported by Fadeyibi et al. (2014) was used to compute weight of material discharge. Assuming resident time of $60 \mathrm{~min}$, including the time for feeding and discharging, the output of the material mixed per g was computed from Eq. (1).

$$
\text { Output }=\frac{\gamma_{\mathrm{c}}}{\mathrm{W}_{\mathrm{t}}} \cdot\left(\frac{\mathrm{V}_{\mathrm{c}} \cdot \mathrm{T}_{\mathrm{c}}}{\mathrm{T}_{\mathrm{e}}}\right)
$$

where:

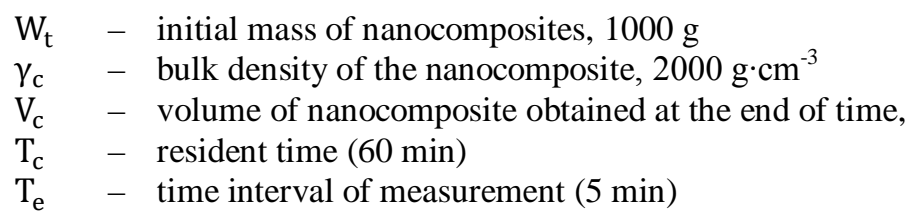

Mixing index of a screw mixer

A degree of distribution and dispersion of nanocomposites was first evaluated as prerequisite for determination of the mixing index of the machine. By assuming that all the particle sizes of starch, glycerol and magnetite nanoparticles are equal, the level of distribution and dispersion was determined from Eq. (2).

where:

$$
S^{2}=\sum_{i=0}^{k} \frac{\left(a_{i}-\bar{a}\right)^{2}}{k}
$$

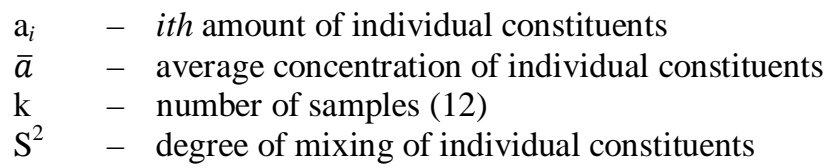

Thus, the mixing index of the screw mixer, which determines homogeneity of the mixing operation, was computed from Eq. (3).

where:

$$
M=\frac{S_{i}{ }^{2}-S^{2}}{S_{i}{ }^{2}-S_{c}{ }^{2}}
$$

$\mathrm{M} \quad$ - mixing index, which ranges from 0 to 1 during the course of the mixing operation, $\mathrm{S}_{\mathrm{c}}{ }^{2}=$ expected standard deviation of the nanocomposites $\left(\mathrm{S}_{\mathrm{c}}{ }^{2} \gg 0\right.$ with subscript $c$ denoting random values composites),

$\mathrm{S}_{i}{ }^{2} \quad-$ product of standard deviation of individual constituents of the nanocomposite, with subscript $i$ denoting initial value of mixing. 
Effect of glycerol...

\section{Amount of unmixed nanocomposites}

The amount of unmixed nanocomposites depends on the mixing rate of the machine, and this was computed from the expression in Eq. (4). It can be seen from the expression that the mixing index is related to the rate of mixing at any time of machine operation.

$$
\frac{\delta M}{\delta t}=K(1-M)
$$

where:

$\mathrm{M} \quad$ - is the mixing index

$\mathrm{K} \quad$ - slope of the graph of $\mathrm{M}$ versus $\mathrm{T}_{\mathrm{e}}$ (time interval of measurement)

Integrating Eq. (4) from $t=0$ to $t=t$ and varying $M$ from 0 to $M_{t}$, the resulting expression in Eq. (5) was used to determine the amount of unmixed nanocomposites (1-M) after 60 min resident time.

$$
(1-M)=e^{-k t}
$$

\section{Modeling and optimization of mixer performance}

Historical Data Surface Response Design (HDSRD) was used to optimize the mixer performance subject to the levels of the process variables, which were the diameter of the holes in the breaker plate $\left(x_{1}=5-7 \mathrm{~mm}\right)$ and glycerol $\left(x_{2}=45-55 \%\right)$. The responses were the output/1000 g, amount of unmixed nanocomposites and mixing index of the machine. Individual experiments, carried out in random order, were represented in Table 1 . The quadratic polynomial regression model, shown in Eq. (6), was assumed for predicting the response variable $(Y)$ (Khuri and Cornell 1987).

$$
Y=\alpha_{o}+\alpha_{1} x_{1}+\alpha_{2} x_{2}+\alpha_{12} x_{1} x_{2}+\alpha_{11} x_{1}{ }^{2}+\alpha_{22} x_{2}{ }^{2}
$$

where:

$Y \quad-\quad$ is the value of predicted performance of the screw mixer,

$x_{1}$ and $x_{2}$ - are the values of diameter of holes in breaker plate and glycerol concentration, respectively,

$\alpha_{0} \quad-\quad$ is the constant value,

$\alpha_{1}$ and $\alpha_{2}$ - are linear coefficients,

$\alpha_{12} \quad-$ is the interaction coefficient,

$\alpha_{11}$ and $\alpha_{22}-$ are quadratic coefficients.

Table 1.

Mixer performance versus variables in HDSRD

\begin{tabular}{lccccc}
\hline \multirow{2}{*}{ Treatment $^{\mathrm{a}}$} & \multicolumn{2}{c}{ Process Variables } & \multicolumn{2}{c}{ Mixer Performance } \\
\cline { 2 - 6 } & $\begin{array}{c}\text { Glycerol } \\
(\%)\end{array}$ & $\begin{array}{c}\text { Breaker Plate } \\
\text { Diameter (mm) }\end{array}$ & $\begin{array}{c}\text { Output per 1000 g } \\
(\mathrm{g} / \mathrm{g})\end{array}$ & $\begin{array}{c}\text { Mixing } \\
\text { Index }\end{array}$ & $\begin{array}{c}\text { Unmixed } \\
\text { Nanocomposites }\end{array}$ \\
\hline 1 & 55 & 5 & 0.558 & 0.607 & 0.393 \\
2 & 50 & 5 & 0.502 & 0.547 & 0.453 \\
3 & 55 & 7 & 0.446 & 0.486 & 0.514 \\
\hline
\end{tabular}


A. Fadeyibi, Z.D. Osunde, M.G. Yisa

\begin{tabular}{lccccc}
\hline & \multicolumn{2}{c}{ Process Variables } & \multicolumn{2}{c}{ Mixer Performance } \\
\cline { 2 - 6 } Treatment $^{\mathrm{a}}$ & $\begin{array}{c}\text { Glycerol } \\
(\%)\end{array}$ & $\begin{array}{c}\text { Breaker Plate } \\
\text { Diameter (mm) }\end{array}$ & $\begin{array}{c}\text { Output per 1000 g } \\
(\mathrm{g} / \mathrm{g})\end{array}$ & $\begin{array}{c}\text { Mixing } \\
\text { Index }\end{array}$ & $\begin{array}{c}\text { Unmixed } \\
\text { Nanocomposites }\end{array}$ \\
\hline 4 & 50 & 7 & 0.402 & 0.438 & 0.562 \\
5 & 45 & 7 & 0.453 & 0.493 & 0.507 \\
6 & 45 & 5 & 0.362 & 0.394 & 0.606 \\
\hline
\end{tabular}

${ }^{*}$ does not correspond to the processing order

\section{Results and Discussion}

\section{Effect of glycerol and holes diameter on machine output}

Effects of glycerol concentration and diameter of holes in breaker plates on the output/ $1000 \mathrm{~g}$ of the screw mixer are shown in Figure 3. The output of the nanocomposites was higher for $5 \mathrm{~mm}$ diameter of the holes in the breaker plate, and lower for its $7 \mathrm{~mm}$ counterpart. This is probably because of the pressure increase accompanying greater force at a lower diameter of the holes in the breaker plate. Lindt and Ghosh (1992) studied the fluid mechanics of the formation of polymer blends and suggested that the degree of mixing increases with the generation of interfacial area between the individual material components and with the residence time. Thus, the shear strain of the mixed composite will play an important role in the generation of this interfacial area (Pinto and Tadmor, 1970).

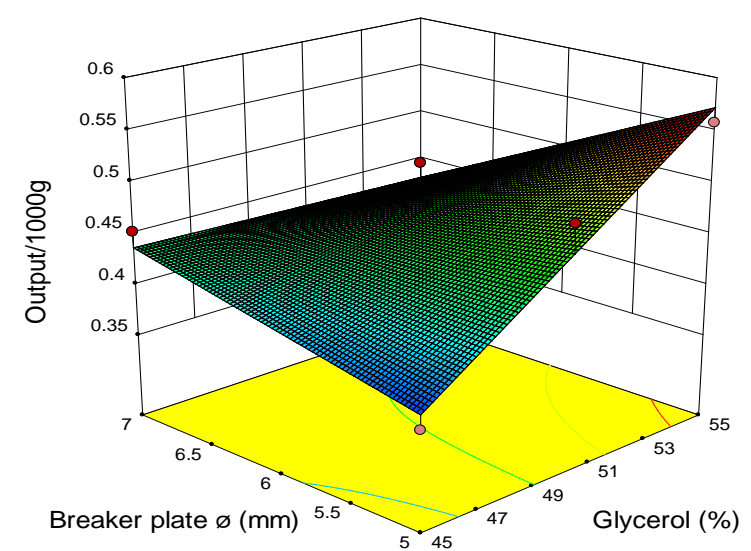

Figure 3. Effect of holes diameter and glycerol concentration on output/1000g $(\mathrm{g} / \mathrm{g})$

\section{Effect of glycerol and holes diameter on the mixing index}

Effects of glycerol concentration and diameter of holes in the breaker plate on the mixing index are shown in Figure 4. It can be observed that the mixing index increased with the corresponding increase in glycerol concentration from $45-55 \%$ and diameter of holes in the 
Effect of glycerol...

breaker plate from 5-7 mm. The mixing index was higher for $5 \mathrm{~mm}$ than in case of $7 \mathrm{~mm}$ diameter of the holes in the breaker plate irrespective of the concentration of glycerol in the nanocomposites. The difference in the mixing index may be attributed to the difference in the force per the unit cross sectional area for the holes acting at the breaker plate. In a related investigation, Fadeyibi et al. (2016b) reported that the mixing index of starch composites increases with concentrations of zinc nanoparticles and diameter of holes in the breaker plate. Research results of Connelly and Kokini (2007) and Sau and Jana (2004) further explained that the performance of a screw mixer increases with the increase in the area of cross section of holes in the breaker plate. Thus, the chance of obtaining the maximum mixing index for nanocomposites containing $45 \%$ of glycerol was 0.35 and this progressively increases with the increase in the diameter of holes in the breaker plate. However, the chance of obtaining a maximum mixing index for $55 \%$ glycerol concentration in the nanocomposites was 0.62 and this progressively decreases with the increase in diameter of holes in the breaker plate. In between these two extreme ends lies the probability of obtaining a higher mixing index for the nanocomposites with $50 \%$ glycerol concentration. Thus, this may mean that the mixer operating at the $5 \mathrm{~mm}$ diameter of the holes in the breaker plate has higher mixing index than the one operating at the $7 \mathrm{~mm}$ diameter of the hole.

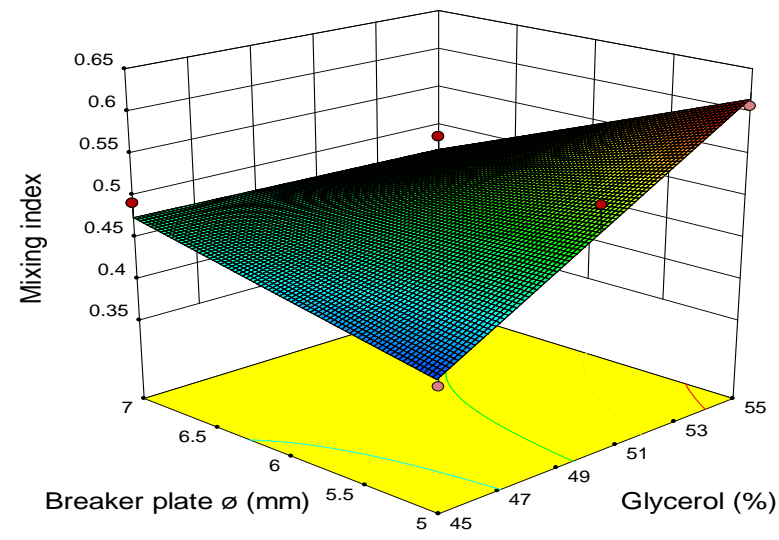

Figure 4. Effect of holes diameter and glycerol concentration on mixing index

\section{Effect of glycerol and holes diameter on amount of unmixed nanocomposites}

Effects of glycerol concentration and the diameter of holes in the breaker plate on the amount of unmixed products in the screw mixer are shown in Figure 5. The amount of unmixed nanocomposites depends on an experimental factor with respect to the mixing rate constant and resident time of mixer operation. The larger the value of the mixing rate efficiency, the lower the amount of the unmixed composite in the barrel of the screw mixer. Ultimately, this determines whether or not to increase the pressure for further mixing by turning the die head to accommodate a smaller diameter of holes in the breaker plate. It can be seen that the amount of unmixed nanocomposites decrease with increase in the concentration of glycerol and the diameter of holes in the breaker plate (Fig. 5). The highest 
amount of unmixed nanocomposites occurs when the die head was turned to accommodate $5 \mathrm{~mm}$ diameter of holes in the breaker plate applied for nanocomposites containing 55\% glycerol concentration. It is important to note that the mixing rate, which determines the amount of unmixed nanocomposites, in the metering region was higher than those in other regions for the screw mixer probably because of higher shear rates associated with transporting nanocomposites (Fadeyibi et al., 2014). Hence, the difference in the amount of unmixed nanocomposites for nanocomposites containing $45 \%$, 50\% and 55\% glycerol concentration.

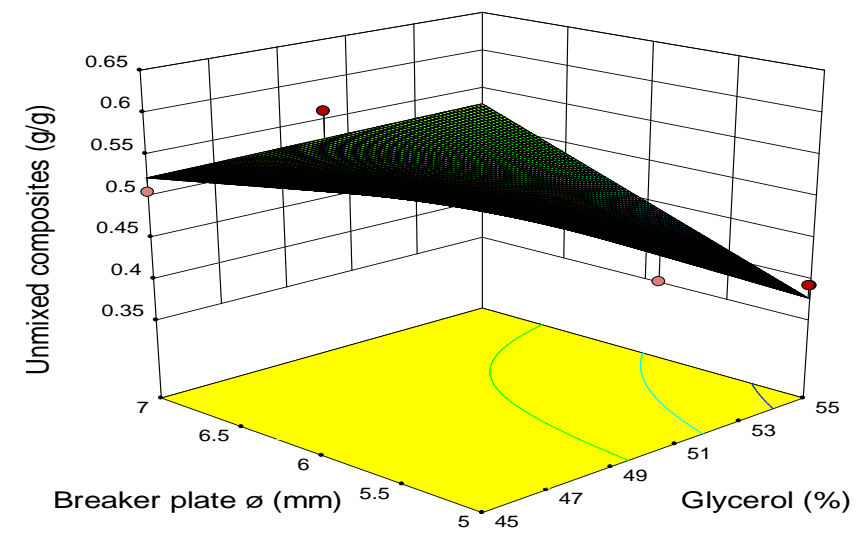

Figure 5. Effect of breaker plate diameter and glycerol concentration on amount of unmixed nanocomposites

\section{Optimization of process variables for maximum mixer performance}

Optimum combinations of the process variables for higher performance of the screw mixer in terms of output, mixing index and amount of unmixed nanocomposites are presented in Figure 6. The results obtained were trained to select the best variable combination of the diameter of holes in the breaker plate and concentration of glycerol by maximizing the mixer performance indices. Therefore, combination experimental variables were randomly and simultaneously compared and their corresponding performances were analyzed collectively (De la Vara and Domínguez, 2002; Fadeyibi et al., 2016b). It can be seen that the maximum mixer output per $1000 \mathrm{~g}$ of the nanocomposites and mixing index lies between $5 \mathrm{~mm}$ diameter of holes in the breaker plate and 55\% glycerol concentration with approximate desirability of 0.6. The high performance of the screw mixer obtained corresponds to the research results of Milán-Carrillo et al. (2012) and Rauwendaal (1986), who investigated the influence of experimental variables of a screw mixer on the optimum performance. Figure 6 clearly shows that the performance of the screw mixer was optimum for the nanocomposites sample, with 55\% glycerol concentration passing through $5 \mathrm{~mm}$ diameter of holes in the breaker plate. Thus, the optimum value can be used in qualifying the performance of the screw mixer. 

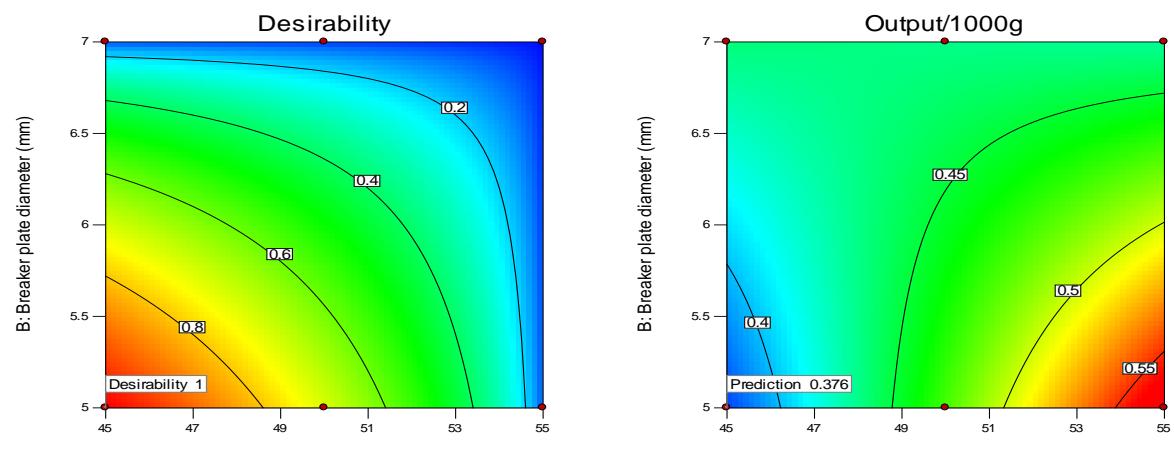

A: Gly cerol (\%)
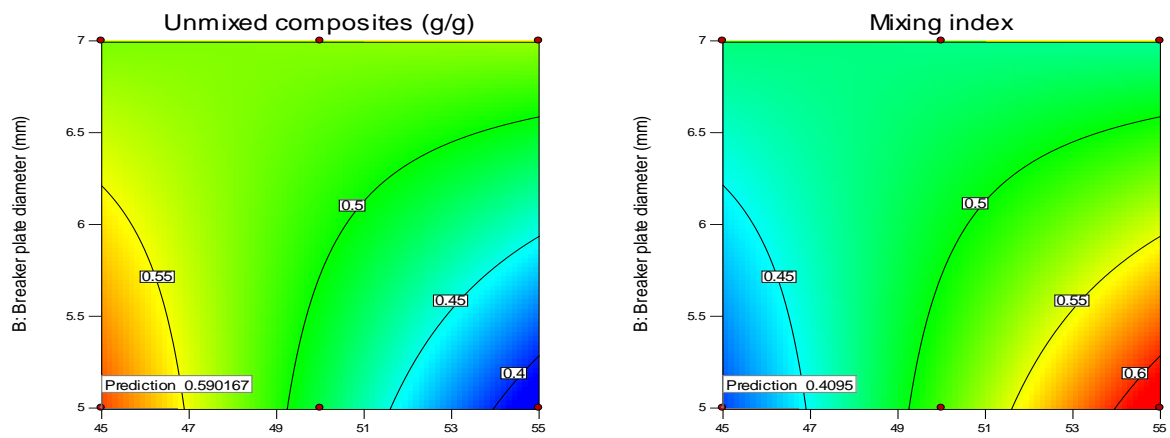

A: Glycerol (\%)

A: Glycerol (\%)

Figure 6. Performance response to optimum process variables

\section{Modelling of mixer performance}

Empirical models for predicting the performance of the screw mixer were proposed in Table 2. The models predict the output, mixing index and amount of unmixed nanocomposites by computing the individual and interactive contributions of glycerol and holes diameter. The contribution of glycerol and diameter of holes in the breaker plate to the overall acceptability of the models were not significant at $\mathrm{p}<0.05$, as shown in Table 3 . Thus, the model can be adapted for a different type of starch and size of the holes in the breaker plate as well as for different types of plasticizer. 
A. Fadeyibi, Z.D. Osunde, M.G. Yisa

Table 2.

Predictors of mixer performance

\begin{tabular}{lccccc}
\hline Performance Indices & Model Equation & $\mathrm{R}^{2}$ & $\mathrm{R}^{2} \mathrm{adj}$ & $\mathrm{AP}$ & $\mathrm{CV}(\%)$ \\
\hline $\begin{array}{l}\text { Output per 1000g } \\
\text { (g/g) }\end{array}$ & $-2.943+0.0704 g+0.4873 b-0.0102 g b$ & 0.889 & 0.725 & 6.556 & 8.07 \\
Amount of unmixed & $4.182-0.0762 g-0.5276 b+0.011 g b$ & 0.888 & 0.721 & 6.498 & 7.92 \\
NC & $-3.1898+0.0763 g+0.528 b-0.011 g b$ & 0.889 & 0.721 & 6.512 & 8.11 \\
Mixing Index & .
\end{tabular}

NC, Nanocomposites; AP, Adequate precision; CV, Coefficient of variation; g, level of glycerol; b, hole diameter

Table 3.

Analysis of variance of mixer performance

\begin{tabular}{lllllll}
\hline Performance & Source of variation & \multicolumn{3}{l}{ Sum of Squares df } & \multicolumn{3}{l}{ Mean Square F- Value p- Value } \\
\hline Output/ 1000g & Model & 0.022 & 3 & $7.22 \times 10^{-3}$ & 5.39 & $0.1605^{\text {ns }}$ \\
& A-Glycerol & $8.93 \times 10^{-3}$ & 1 & $8.93 \times 10^{-3}$ & 6.66 & $0.1230^{\text {ns }}$ \\
& B- Holes diameter & $2.44 \times 10^{-3}$ & 1 & $2.44 \times 10^{-3}$ & 1.82 & $0.3097^{\text {ns }}$ \\
& AB & 0.01 & 1 & 0.01 & 7.69 & $0.1092^{\text {ns }}$ \\
& Residual & $2.68 \times 10^{-3}$ & 2 & $1.34 \times 10^{-3}$ & & \\
& Cor Total & 0.024 & 5 & & & \\
\hline Unmixed NC & Model & 0.026 & 3 & $8.50 \times 10^{-3}$ & 5.3 & $0.1629^{\text {ns }}$ \\
& A-Glycerol & 0.011 & 1 & 0.011 & 6.58 & $0.1242^{\text {ns }}$ \\
& B- Holes diameter & $2.89 \times 10^{-3}$ & 1 & $2.89 \times 10^{-3}$ & 1.8 & $0.3120^{\text {ns }}$ \\
& AB & 0.012 & 1 & 0.012 & 7.51 & $0.1114^{\text {ns }}$ \\
& Residual & $3.21 \times 10^{-3}$ & 2 & $1.61 \times 10^{-3}$ & & \\
& Cor Total & 0.029 & 5 & & & \\
\hline Mixing Index & Model & 0.026 & 3 & $8.52 \times 10^{-3}$ & 5.31 & $0.1625^{\text {ns }}$ \\
& A-Glycerol & 0.011 & 1 & 0.011 & 6.61 & $0.1238^{\text {ns }}$ \\
& B- Holes diameter & $2.86 \times 10^{-3}$ & 1 & $2.86 \times 10^{-3}$ & 1.78 & $0.3136^{\text {ns }}$ \\
& AB & 0.012 & 1 & 0.012 & 7.54 & $0.1110^{\text {ns }}$ \\
& Residual & $3.21 \times 10^{-3}$ & 2 & $1.61 \times 10^{-3}$ & & \\
& Cor Total & 0.029 & 5 & & & \\
\hline
\end{tabular}

$\mathrm{NC}=$ Nanocomposites, $\mathrm{ns}=$ not significant at $\mathrm{p}<0.05$

\section{Conclusion}

Effect of glycerol and diameter of holes in the breaker plate on the performance of the screw mixer for nanocomposites was investigated in this research. The output per $1000 \mathrm{~g}$ of the nanocomposites and the mixing index increased while the amount of unmixed nanocomposites decreased with a higher diameter of holes in the breaker plate (not significant at $\mathrm{p}<0.05$ ). The optimum performance of the mixer lies generally between $5 \mathrm{~mm}$ diameter of holes in the breaker plate and 55\% glycerol concentration with an approximate desirability of 0.60 . The empirical models developed are fit $\left(\mathrm{R}^{2}=0.89, \mathrm{p}<0.05\right)$; and there were no sig- 
Effect of glycerol...

nificant differences between the actual and predicted values of the mixer performance. The results suggest $5 \mathrm{~mm}$ diameter of holes in the breaker plate of the screw mixer for homogenizing nanocomposites with optimum performance.

\section{References}

Anuku, A. (2012). Chemical and biochemical synthesis of magnetite nanoparticles in detection and treatment of breast cancer. A paper presented at 5 day workshop in the Federal University of Technology, Minna, Nigeria in collaboration with African University of Science and Technology, Abuja, Nigeria. pp. 1-12. https://doi.org/10.1557/jmr.2012.317.

Azeredo, H. M. C. (2009). Nanocomposites for food packaging applications. Food Research International, 42(9), 1240-1253.

Connelly, R. K., Kokini, J.L. (2007). Examination of the mixing ability of single and twin screw mixers using 2D finite element method simulation with particle tracking. Journal of Food Engineering, 79(3), 956-969.

De la Vara, S. R., Domínguez, D. J. (2002). Métodos de Superficie De Respuesta, Un Estudio Comparativo. Revista de Matemáticas Teoríay Aplicaciones, 1(1), 47-65.

Fadeyibi, A., Osunde, Z.D., Agidi, G., Egwim, E.C. (2016a). Design of single screw extruder for homogenizing bulk solids. Agricultural Engineering International: CIGR Journal, 18(4), 222-231.

Fadeyibi, A., Osunde, Z.D., Agidi, G., Egwim, E.C. (2016b). Mixing index of a starch composite extruder for food packaging application. In: Inamuddin S. (Editor): Green polymer composites technology: properties and applications. CRC press and Taylor\&Francis Group. ISBN 9781498715461.

Fadeyibi, A., Osunde, Z.D., Agidi, G., Evans, E.C. (2014). Flow and strength properties of cassava and yam starch-glycerol composites essential in the design of handling equipment for granular solids. Journal of Food Engineering, 129, 38-46.

Jahani, M., Alizadeh, M., Pirozifard, M., Qudsevali, A. (2008). Optimization of Enzymatic Degumming Process for RBO Using Response Surface Methodology. LWT - Food Science and Technology, 41(10), 1892-1898.

Hu, D. D., Chen, J. N. (2006). Simulation of polymer melt flow fields in intermeshing co-rotating three-screw extruders, Journal of Beijing Institute of Technology, 15(3), 360-365.

Joe-Tools Precision Design and Manufacturing (2009). Complete design and manufacturing resource for premium quality extrusion products that include innovative and industry standard Crossheads, Tips, Dies, Screws, Barrels, Breaker Plates and all accessories. http://www.joe-tools. com/int_crossheads.html.

Khuri, A. A., Cornell, J. A. (1987). Response Surfaces: Designs and Analyses, Marcel Dekker Inc., New York, pp. 1-17, 254. ISBN 9780824797416.

Lindt, J.T., Ghosh, A.K. (1992). Fluid mechanics of the formation of polymer blends. Part I: Formation of lamellar structures. Polymer Engineering Science, 32, 1802-1813.

Lee, T. H., Kwon, T. H. (1999). A new representative measure of chaotic mixing in a chaos singlescrew extruder. Advances in Polymer Technology, 18(1), 53-68.

Milán-Carrillo, J., Montoya-Rodríguez, A., Gutiérrez-Dorado, R., Perales-Sánchez, X., ReyesMoreno, C. (2012). Optimization of Extrusion Process for Producing High Antioxidant Instant Amaranth (Amaranthus hypochondriacus L.) Flour Using Response Surface Methodology. Applied Mathematics, 3, 1516-1525.

Pinto, G., Tadmor, Z. (1970). Mixing and Residence Time Distribution in Melt Screw Extruders. Polymer Engineering Science, 10, 279-288.

Rauwendaal, C. (1986). Polymer Extrusion. Hanser Publishers, Munich. ISBN 3-446-14196-0. 
Sau, M., Jana, S. C. (2004). A study on the effects of chaotic mixer design and operating conditions on morphology development in immiscible polymer systems. Polymer Engineering and Science, 44(3), 407-422.

Potente, H., Ansahl, J., Klarholz, B. (1994). Design of Tightly Intermeshing Co-Rotatin Twin Screw Extruders, Intern. Polymer Processing IX, Hanser Publishers, Munich. Book ISBN 978-1-56990516-6

\section{WPLYW GLICEROLU I ŚREDNICY OTWORÓW W PLYCIE SITOWEJ NA WYDAJNOŚĆ MIKSERA ŚLIMAKOWEGO DO NANOKOMPOZYTÓW}

Streszczenie. Płyta sitowa mieszalnika ślimakowego jest skutecznym narzędziem mieszalniczym stosowanym do homogenizacji nanokompozytów. Prace badawcze podjęto w celu zbadania wpływu glicerolu i średnicy otworów w płycie sitowej na wydajność mieszalnika nanokompozytów. Próbki nanokompozytów powstały przez połączenie $1000 \mathrm{~g}$ skrobi z manioka, 45-55\% glicerolu i $2 \%$ nanocząsteczek magnetytu. Zastosowano je do oceny wydajności mieszalnika przy średnicy otworów w płycie sitowej wynoszącej 5 i $7 \mathrm{~mm}$. Wpływ glicerolu i średnicy otworów w płycie sitowej na wskaźnik mieszania, ilość niezmieszanych nanokompozytów i wynik/ 1000 g oceniono jako wskaźnik wydajności dla 1 godziny. Określono modele empiryczne w celu przewidzenia wydajności mieszalnika w ramach określonych kryteriów. Wyniki pokazują, że wydajność/1000 g i wskaźnik mieszania zwiększyły się razem ze wzrostem glicerolu i średnicy otworów w płycie sitowej $(\mathrm{p}<0.05)$. Maksymalna wydajność/ $1000 \mathrm{~g}$ i wskaźnik mieszania znajdują się pomiędzy średnicą otworów wynoszącą $5 \mathrm{~mm}$ a $55 \%$ stężenia glicerolu przy zbliżonej pożądanej wartości wynoszącej 0.60 . Przygotowane modele empiryczne były odpowiednie $\left(\mathrm{R}^{2}=0.89, \mathrm{p}<0.05\right)$, nie odnotowano żadnych istotnych różnic pomiędzy istniejącymi a przewidywanymi wartościami. Wyniki sugerują zastosowanie otworów o średnicy $5 \mathrm{~mm}$ do homogenizacji nanokompozytów i osiągnięcia optymalnej wydajności.

Słowa kluczowe: płyta sitowa, wskaźnik mieszania, nanokompozyty, mieszalnik ślimakowy 